\title{
AN INTERPRETIVE ACCOUNT OF UNCONSCIONABILITY IN TRUST LAW
}

\author{
Eben $\mathrm{Nel}$
}

BJuris LLB LLM LLD

Advocate of the High Court of South Africa

Research Associate, Faculty of Law, Nelson

Mandela Metropolitan University, Port Elizabeth

\section{SUMMARY}

The principle of public policy and factors such as fairness, reasonableness and good faith have - since the introduction of constitutionalism in South African law - become the cornerstone of the law and of its impact on all relationships - even the relationships in contracts. One such development is the assimilation of the doctrine of unconscionability in contract law. In this article, this concept, within the context of a trust formed by way of contract, is investigated. While the doctrine of unconscionability is not without controversy, the question arises as to whether it has any role to play in trust law. The two-pronged approach traditionally used to determine the presence of an unconscionable contract or term is evaluated in light of its potential application in the case of trust deeds. The author submits that the incorporation of the doctrine will be advantageous in the developmental process in respect of a new constitutional trust-law order that is in harmony with the spirit, purport and objects of the Constitution. The doctrine of unconscionability has become a reality in South African law of contract; it should therefore also be embraced in the establishment of the trust as a dynamic tool in the commercial environment.

\section{INTRODUCTION}

The contract as an agreement between two or more parties, giving rise to particular enforceable obligations, is subject to certain important qualifications. ${ }^{1}$ The enforceability of an agreement may be challenged among others on the basis of unconscionability. For the purposes of this article, the doctrine of unconscionability is to be understood as a defence against a term or terms in a contract that is/are so unjust, unfair and/or unreasonable to a given party to that contract that no reasonable or informed person would agree to it. ${ }^{2}$ This is not an attempt to limit the principle to a

See Peel The Law of Contract (2010) 1-7.

2 Chief Justice Fuller in Hume $v$ United States 132 U.S. 406, 411 (1889) stated that an unconscionable contract is an agreement "such as no man in his senses and not under delusion would make on the one hand, and as no honest and fair man would accept on the other ..." The two factors that most often justify the application of the doctrine are those of unfairness and vulnerability. 
particular definition, however, as that may do more harm than good. As the purpose of the doctrine is to empower the courts to police certain behaviour, a concrete definition may tie their hands unnecessarily. ${ }^{3}$

In the United States, a number of factors have been identified which are considered to determine the presence of an unconscionable term in a contract. These include such factors as duress, undue influence, deceit, mistake, fraud, violence, absence of cause, abuse of confidence, coercion, misrepresentation, forfeiture, restraint of trade, and estoppel. ${ }^{4}$ In many common-law jurisdictions, the concept has moved very close to being accepted as a type of general defence, although the courts are still cautious in their application thereof. In other jurisdictions, such as the United Kingdom, the concept has changed, so that it is now "part of the background for the application of a small number of narrowly defined defences."

In South Africa, factors such as fairness, reasonableness and good faith in evaluating the enforceability of contracts have been debated at length by the courts and academics alike. ${ }^{6}$ Since the advent of constitutionalism, the values entrenched in the bill of rights, such as dignity and equality, have further contributed to some of the uncertainty experienced in these evaluations. The principle of public policy has also been extended in this process to include factors such as ubuntu and conscionability. ${ }^{7}$

In this essay, the legal reality of the principle of unconscionability within the context of a trust formed by way of contract will be investigated. The aim is to focus on the interpretive understanding of the particular issue under investigation, within the historical and descriptive reality, ultimately culminating in a prescriptive account. ${ }^{8}$

3 Stuntebeck "The Doctrine of Unconscionability" 1968 Maine LR 8191 submits that the real value of the doctrine lies in the policing aspect thereof, as skilled draftsmen of contracts often lose sight of the general principles of "fairness and decency". DiMatteo and Rich "A Consent Theory of Unconscionability: An Empirical Study of Law in Action" 200633 Florida State University $L R 10661080$, refer to the difficulty of a fixed definition in a section called "Defining the Undefinable".

4 See s 2-302 of the Uniform Commercial Code. The Code was originally enacted in 1952 and has been amended many times since. The Code is not itself the law, but only a recommendation of the laws that should be adopted in the different states. States may either adopt the Code as is or may adopt it with particular changes.

5 Smith Contract Theory (2004) 341.

6 See Hutchison "Reciprocity in Contract Law" 20131 Stellenbosch LJ 3 29, where he states that "the pendulum is swinging from a climate of classical contract law to a more altruistic vision", referring to the influence of public policy on contractual freedoms.

7 See Lewis "The Uneven Journey to Uncertainty in Contract" 2013 76(1) THRHR 8182. Public policy and the boni mores are described as being "deeply rooted in the Constitution and its underlying values" in Bredenkamp v Standard Bank of SA Ltd 2010 (4) SA 468 (SCA) par [39]. In Everfresh Market Virginia (Pty) Ltd v Shoprite Checkers (Pty) Ltd 2012 (1) SA 256 (CC) in par [26] it is stated that issues of public policy cannot be considered without reference to s 39(2) of the Constitution, requiring the development of all law to adhere to the spirit, purport and objects of the Bill of Rights.

8 See Smith Contract 4-6 for the four types of accounts in law, namely historical, prescriptive, descriptive and interpretive. "Historical" refers to the causal history of the particular legal principle; "prescriptive" refers to the ideal law; "descriptive" is a reference to the real law; and an "interpretive" account is an analysis of the law. 


\section{WHAT CONSTITUTES UNCONSCIONABILITY?}

It has been argued that the underlying principle of the doctrine of unconscionability is the protection of the basic human right to due process of law. In practical terms, therefore, it is a purposeful protection of the weak against the strong. ${ }^{9}$ It is not without contention, however, since it walks the tightrope between the right to due process and the notion of contractual freedom, tempered as it is by the socio-economic realities of a particular place and time. ${ }^{10}$ The test for unconscionability should, therefore, be applied objectively, but with due consideration to the particular set of facts.

Schmitz ${ }^{11}$ submits that the formalistic approach to contract law does not reflect reality and fails to promote normative values such as fairness. There are times when classical contract law defences such as mistake, fraud or duress are not adequate to protect the values of justice and fairness. This is when the flexibility of unconscionability becomes a safety net in the hands of the courts.

There has traditionally been concern that tampering with the sanctity of contracts will impact negatively on legal and commercial certainty. An overprotection of the weak, uneducated or economically disadvantaged may prejudice those very same people, as stronger parties will be discouraged from concluding contracts with them. In the final instance, however, it could be argued that sufficient protection by way of contractual principles such as justifiable mistake, duress, undue influence and misrepresentation do exist as do the huge number of existing legislative interventions in many jurisdictions. ${ }^{12}$

Although it may seem, therefore, as if the right of contractual freedom is inconsistent with the right to due process, it is submitted that it is not the freedom of contract that is inhibited, but the abuse of that freedom. The fact that unequal parties may contract freely with one another does not necessarily mean that they are equally free. A significantly unequal relationship between the parties to the contract, which leaves one of the parties without a meaningful level of bargaining power, combined with terms that are unreasonably favourable to the other party, may contribute to such a level of one-sidedness that a court of law may find the effect

9 Dolinger "Unconscionability Around the World: Seven Perspectives on the Contractual Doctrine" 1992 14(3) Loyola of Los Angeles International and Comparative LJ 435 437. See also Barnard A Critical Legal Argument for Contractual Justice in the South African Law of Contract (LLD thesis University of Pretoria 2005) 235-246 for an evaluation of the human rights element in contract law.

10 Dolinger 1992 14(3) Loyola of Los Angeles International and Comparative LJ 436.

11 Schmitz "Embracing Unconscionability's Safety Net Function" 2006 58(1) Alabama LR 73 74, 117. Compare Barnard A Critical Legal Argument for Contractual Justice in the South African Law of Contract 201 on the global support for a doctrine of contractual justice.

12 Compare "Investigation into Unreasonable Stipulations in Contracts and the Rectification of Contracts" (Project 47) Discussion Paper 65, 7 August 1996, Media Statement by the South African Law Commission. See the Consumer Protection Act 68 of 2009. In the UK, the most important legislative limitations on exemption clauses are contained in the Unfair Contract Terms Act of 1977 and the Unfair Terms in Consumer Contracts Regulations of 1999. 
unconscionable. ${ }^{13}$ This again carries the risk of prejudicial effects on commercial activity and stability, as the marketplace requires from contracting parties to honour their commitments. ${ }^{14}$

Determining the reasonableness of a contract may be based on factors such as the particular commercial setting, the purpose of the contract and the ultimate effect thereof. In evaluating the commercial setting of the contract, a number of aspects should be considered: the history of the agreement, the factors leading to the agreement, the business risks involved, and the distribution of such risks among the parties to the agreement. $^{15}$

The certainty of law in a particular jurisdiction, combined with the profile of the judiciary, should instil the necessary confidence and trust in the business arena to enable contracting parties to exercise their freedom of contract effectively. The stronger party must believe that an agreement will be honoured, while the weaker party must believe that he/she will not be unconscionably prejudiced.

Within this ideal of certainty it seems, however, that a form of deterrence is necessary to protect the contract as a useful and acceptable medium for all parties to reach agreeable consensus. It is imperative that the development of the doctrine of unconscionability creates clear guidelines of fairness and deters vague premises of decision-making, should - in the first place - the judiciary accept its purpose and value to give effect to the purported outcomes. ${ }^{16}$

Although the doctrine enables courts to decline to enforce contracts whose terms are seriously one-sided, overreaching, exploitative or otherwise fundamentally unfair, ${ }^{17}$ it must be considered that some unconscionable contracts are made freely and with full information by the prejudiced party. ${ }^{18}$ If the general principle that parties to a contract should honour their commitments is not jealously guarded, the commercial arena may fall into disarray. To overcome the presumption that people usually contract in their own best interest, it must be proved that either the negotiation process was

13 Compare Williams v Walker-Thomas Furniture Co. 350 F.2d 445, 449 (1965). See also Murphy v McNamara, 38 Conn. Super 183, 416 A 2d 170 (1979), where it was decided that unequal bargaining power resulting in an unconscionable purchase price constitutes an unfair trade practice.

14 In Rowe $v$ Great Atlantic \& Pacific Tea Company 385 N.E.2d 566 (N.Y. 1978) 569 the court referred to the "unavoidable tension between the concept of freedom of contract" and the need to protect society against "the potentially harsh effects of an unchecked free market system".

15 See In Re Elkins-Dell Manufacturing Co. 235.F.Supp 864, 873 (E.D. Pa 1966).

16 See Stuntebeck 1968 Maine LR 91.

17 Watt Trusts and Equity (2006) 76 submits that the term "unconscionability" "defines itself against a background of established laws of general application" and "describe(s) an oppressive abuse of legal rights and powers".

18 It is sometimes argued that interference in a matter where the parties contracted while being fully aware of the objectionable terms, is paternalistic in nature. 
tainted by duress or fraud, or that the term sought to be enforced is in violation of public policy. ${ }^{19}$

In the United States an evaluative system, distinguishing between procedural and substantive aspects of unconscionability, was developed. ${ }^{20}$ This developmental process did not come without major challenges. In cases where both procedural and substantive unconscionable behaviour are detected, the effect may be evident. Where, however, one form of unconscionability does exist but the other aspect is totally absent, or there is little evidence thereof, it remains a question whether interference by the court is justifiable or not. ${ }^{21}$

Some courts were satisfied when either procedural or substantive unconscionability had been proved, while others set a minimal threshold of evidence for both forms of unfairness. This sliding-scale approach usually requires a higher degree of unconscionability of the one form if a lower degree had been detected in the other. ${ }^{22}$ The process ultimately developed into the courts identifying a number of factors that might add up to a sum total of unconscionability.

Forms of procedurally unconscionable stipulations in contracts that manifested through the courts are: hidden or non-conspicuous clauses; the use of incomprehensible language to the layperson; inequality of bargaining powers between the parties to the agreement; exploitation of the underprivileged, unsophisticated, uneducated or illiterate; factors such as age, education, intelligence, business acumen, experience, and relative bargaining power; as well as who drafted the agreement, whether certain terms were explained, whether alterations were possible, and whether there were alternative sources of supply available. ${ }^{23}$

Factors regarded as being substantively unconscionable included excessive pricing, significant cost-price disparity, denial of basic rights and remedies, the inclusion of penalty clauses, the limitation of liability, and an overall imbalance in the transaction. ${ }^{24}$

\section{UNCONSCIONABILITY IN SOUTH AFRICAN LAW}

The term "unconscionable" was first introduced to South African law jargon in 1983 when it was decided in Botha $v$ Van Niekerk ${ }^{25}$ that personal liability would become justifiable only when it was clear that the third party suffered

19 Marrow "Squeezing Subjectivity from the Doctrine of Unconscionability" 200553 Cleveland State LR 187 195. See Wertheimer "Unconscionability and Contracts" in May and Brown (eds) Philosophy of Law: Classic and Contemporary Readings (2009) 487-499.

20 Since Williams v Walker-Thomas Furniture Company 350 F.2d 445 (D.C. Cir. 1965) the courts evaluated two aspects: unfairness in formation of the contract, and excessively disproportionate terms. See in this regard Sitogum Holdings Incorporated 800 A.2d 921. DiMatteo and Rich 2006 Florida State University LR 1073-1075.

Ibid.

DiMatteo and Rich 2006 Florida State University LR 1076-1080.

Ibid.

1983 (3) SA 513 (W). 
an "unconscionable injustice" because of the unjust actions of the liable party. ${ }^{26}$ The concept of unconscionability did not, however, receive much attention either from academics or from the judiciary. ${ }^{27}$

In 1998, the South African Law Commission had to determine whether courts should be able to give relief to unfortunate contractual parties. The main argument against such a development was the risk it posed for legal and commercial certainty, while there was already some protection in place as far as justifiable mistake, duress, undue influence and fraudulent, negligent and innocent misrepresentations were concerned. ${ }^{28}$ The Commission acknowledged that individuals often enter into contracts with one another (or with institutions or businesses), with particular expectations, only to find subsequently that, in practical application, the contracts (or parts thereof) "are unjust or unconscionable". ${ }^{29}$

The Commission consequently recommended in its report that a court should indeed be able to interfere in a contract when it is of the opinion that the way the contract came into being, or the form, execution or enforcement thereof, was "unreasonable, unconscionable or oppressive". ${ }^{30}$ The specific guidelines for determining such procedural or substantive unfairness ${ }^{31}$ were listed as follows:

(a) the bargaining strength of the parties relative to each other;

(b) reasonable and commonly accepted standards of fair dealing;

(c) the extent of negotiations entered into;

(d) the reasonable practicality of renegotiation of certain terms; and

(e) the context of the contract as a whole.

26 See Botha $v$ Van Niekerk supra 525E-F. See Che and Spier Strategic Judgment Proofing (2008) Harvard Law and Economic Discussion Paper no 618 http://papers.ssm.com/ sol3/papers.cfm?abstractid=1159184 (accessed 2011-08-06).

27 In Carmichelle v Minister of Safety and Security 2001 (4) SA 938 (C) it was confirmed that courts are obliged to consider whether the existing common law requires development in accordance with the objectives laid down in s 39(2) of the Constitution.

28 South African Law Commission Report: Project 47 "Unreasonable Stipulations in Contracts and the Rectification of Contracts" par 1.7 and further. See the reference in par 1.9 to Bank of Lisbon and South Africa Ltd v De Ornelas 1988 (3) SA 580 (A).

29 South African Law Commission Report: Project 47 "Unreasonable Stipulations in Contracts and the Rectification of Contracts" April 1998 par 1.3. The object of the project, according to par 1.1, was "to consider whether courts should be enabled to remedy contracts or contractual terms that are unjust or unconscionable ..." The Bill on the Control of Unreasonableness, Unconscionability or Oppressiveness in Contracts or Terms was unsuccessfully tabled before Parliament in September 1998.

30 South African Law Commission Final Report on Project 47: Unreasonable Stipulations in Contracts and the Rectification of Contracts 1998 213-218. See Glover The Doctrine of Duress in the Law of Contract and Unjustified Enrichment in South Africa (DPhil thesis Rhodes University 2003) 373-376, submitting that "the terms 'unconscionability' and 'good faith' would probably seem like two sides of the same coin".

31 See Horton "Unconscionability in the Law of Trusts" 2008 Law Review 18-19 http://ssrn. com/abstract $=1280363$ (accessed 2011-08-06) for a discussion on the differences between procedural and substantive conscionability. 
Appropriate protection mechanisms were proposed, which included peremptory cooling-off periods, the exemption of "voetstoots" clauses, and a general prohibition against standard-form contracts. ${ }^{32}$ Those in favour argued for a balance between "the principle of freedom of contract, on the one hand, and the counter-principle of social control over private volition in the interest of public policy, on the other". ${ }^{33}$ The necessity for particular interventions was identified, as there was no "general theory of unconscionability allowing a court to interfere with a contractual relationship merely on the ground of unfairness".

Although the doctrine was not known in South African law, the courts did manage to find ways to deal with matters of gross unfairness in contractual law. In Cape Pacific, ${ }^{35}$ for example, the court used the test of policy considerations, such as fraud, dishonesty, improper conduct, an improper purpose or where the company was used as a facade, when a piercing of the corporate veil was considered. ${ }^{36}$ In the Potgieter case ${ }^{37}$ Brand JA criticises the interpretation of the court a quo where it submits, with reference to Barkhuizen $v$ Napier, ${ }^{38}$ that "as a matter of public policy, our courts can refuse to give effect to the implementation of contractual provisions which it regards as unreasonable and unfair". It was submitted by the court that "reasonableness and fairness are not freestanding requirements for the exercise of a contractual right" ${ }^{39}$ Values such as good faith, reasonableness and fairness, are therefore not to be regarded as "independent substantive rules" of contract $^{40}$ and courts may not subjectively decide that a particular contractual term contravenes such a value or values. ${ }^{41}$

A decade after the recommendations by the Law Commission, the legislator introduced the concept of unconscionability to South African law, when the term "unconscionable" was defined in the Consumer Protection $\mathrm{Act}^{42}$ as "having a character contemplated in section 40; or otherwise unethical or improper to a degree that would shock the conscience of a reasonable person". Section 40 explains "unconscionable behaviour", in the specific context, as the use of physical force, coercion, undue influence,

32 Law Commission Report par 1.11 and 1.12.

33 Law Commission Report par 1.30-1.32. The old English principle as laid down in Evans $v$ Llewellyn [1787] 29 ER 1191 was referred to, namely "if the party is in a situation in which he is not a free agent and is not equal to protecting himself, this Court will protect him/her". Law Commission Report par 1.34

35 Cape Pacific Ltd v Lubner Controlling Investments (Pty) Ltd 1995 (4) SA 790 (A).

36 See Cape Pacific Ltd v Lubner Controlling Investments (Pty) Ltd supra 802F-805F. In 803I$\mathrm{J}$ it is stated that it is a matter of "substance rather than of form in order to arrive at the true facts".

37 Potgieter v Potgieter NO 2012 (1) SA 637 (SCA) par [32].

382007 (5) SA 323 (CC). Ngcobo J. explains in Barkhuizen par [80] that the notion of "good faith" includes concepts such as justice, reasonableness and fairness.

39 Potgieter v Potgieter supra par [32]. Brand JA refers to Bredenkamp v Standard Bank of SA Ltd supra par [53].

40 Potgieter v Potgieter supra par [32].

41 Compare Barkhuizen v Napier supra par [82], where the court states that a doctrine such as "good faith" is not "a self-standing rule" but merely an underlying contractual value.

42 Act 68 of 2009. 
pressure, duress, harassment, unfair tactics or other similar conduct. It further describes as "unconscionable" the taking of advantage of a consumer who is "substantially unable" to protect himself/herself, because of physical or mental disability, illiteracy, ignorance, inability to understand the language of an agreement or other similar factors.

It is submitted that the strong and ineloquent wording used in the Consumer Protection Act to describe the concept of unconscionability, is not consonant with the development of the doctrine in most contract-law jurisdictions.

The legislature further introduced the unconscionability concept by way of section 20 of the Companies Act. ${ }^{43}$ This section deals with the validity of company actions in general and subsection 20(9) stipulates that "if a court finds that the incorporation of the company, any use of the company, or any act by or on behalf of the company, constitutes an unconscionable abuse of the juristic personality of the company as a separate entity", the court may declare the corporate veil to have been pierced in respect of any right, obligation or liability of the company or of a shareholder of the company.

It is submitted that the test for unconscionability in the Companies Act would often differ substantially from the near crudeness of the behaviour referred to in the Consumer Protection Act. The purpose in both pieces of legislation is to protect the weaker party against the stronger party in the business relationship. In terms of the Companies Act, it may often be a more subtle and sophisticated form of behaviour that would constitute unconscionability.

Section 20(6) grants recourse to the shareholders against anyone who "intentionally, fraudulently or due to gross negligence causes the company to do anything inconsistent" with the Act or certain limitations, restrictions or qualifications.

Section 20(9) codified the doctrine of piercing the corporate veil, and the statutory remedy in subsection 20(9)(a) grants the courts the opportunity to discard the separate legal personality of the company on the basis that it was misused. ${ }^{44}$ Even shareholders may be held liable by any interested party. This may incentivise all stakeholders to uphold the integrity of the corporation and its actions in all proceedings and business transactions. It may be difficult to determine when a company was used for abusing practices or when abusing practices were conducted on behalf of the corporation. ${ }^{45}$ Subsection 20(9)(b) stipulates that a court may make any further order the court considers appropriate to give effect to a declaration that a particular company has lost its juristic personality. Some suggest that this codification may give shareholders the incentive to make provision in the

4371 of 2008.

44 Other instances where a company's separate legal personality may be ignored are in terms of s 165 (derivative actions), 161(1)(b) and 218(2) (civil actions). See Stein The New Companies Act Unlocked - A Businessperson's Guide (2011) 374-375.

45 See Schoeman "Piercing the Corporate Veil under the New Companies Act" June 2012 De Rebus 26 28, submits that the legislature followed the same conservative approach that the courts have followed before, and that the term "unconscionable" highlights this approach. 
memorandum of incorporation to protect themselves against certain actions by the directors of the company. ${ }^{46}$

The principle of unconscionability has not been introduced to South African law in a very orderly fashion, although it was suggested by the South African Law Commission many years ago. ${ }^{47}$ Instead of a haphazard legislative incorporation of the doctrine, Berat advocated the introduction of the concept to South African law by way of a new commercial code that will harmonise it with the existing doctrines of misrepresentation, duress, and undue influence. ${ }^{48}$ It is submitted that, even when a flexible contract-law approach is favoured over the historical formalistic approach, the legislator and the courts still have a duty to implement new contractual concepts with care and wisdom. ${ }^{49}$

It is generally accepted that the doctrine of unconscionability requires both a procedural and a substantive element. Although the courts will have to determine the exact contents thereof, it has been submitted that "an unconscionable abuse" will require mala fides on the part of the individual or company representative, resulting in substantive unfairness to the other contracting party. ${ }^{50}$ The question remains whether there is a need for a statutory definition for the concept of unconscionability and the precise contents of the doctrine, or whether the courts should be allowed to develop their own understanding of it. ${ }^{51}$

\section{UNCONSCIONABILITY IN THE CONTEXT OF TRUST LAW}

It is trite law that many inter vivos trusts are created by way of contract. This does not, however, make such a trust a contract, as it is merely an

46 See "Access to Justice: Human Rights Abuses Involving Corporations - South Africa", a project of the International Commission of Jurists, Geneva, Switzerland, 2010, 8-10 www.icj.org (accessed 2011-02-12), where it is proposed that the memorandum should include a clause stipulating that one of the purposes of the company is to uphold the Bill of Rights entrenched in the Constitution. As such, a stipulation will make actions contrary thereto ultra vires, and shareholders can act against directors not abiding thereto.

47 The doctrine of unconscionability is known to Canada, Australia and the United Kingdom and was legislated in the United States' Uniform Commercial Code, s 2-302.

48 Berat "South African Contract Law: The Need for a Concept of Unconscionability" in May and Brown (eds) Philosophy of Law: Classic and Contemporary Readings (2009) 487-499. See also Lloyd "The 'Circle of Assent' Doctrine: An Important Innovation in Contract Law" 2006 7(2) Tennessee Journal of Business Law 237-271 and the connection between the "circle of assent" doctrine and the doctrine of "unconscionability".

49 See Schmitz 2006 58(1) Alabama LR 73-79 and 117-118 for the argument in favour of a more flexible contract law approach.

50 See Glover The Doctrine of Duress in the Law of Contract and Unjustified Enrichment in South Africa (DPhil thesis Rhodes University 2003) 373-443. Berat in May and Brown (eds) Philosophy of Law 501-510 argues in support of the integration of the doctrine in the SA jurisdiction as a matter of fairness to a less educated population. See also Berat "South African Contract Law: The Need for a Concept of Unconscionability" 199214 Angeles International and Comparative LJ 507-527. For application of the doctrine, see Marrow 2005 Cleveland State LR 187-224. This concept will be discussed in more detail in 4.6.8.

51 See Stuntebeck 1968 Maine LR 81-91 in this regard. 
explanation of the legal process followed to bring the trust into being ${ }^{52}$ For a trust to manifest in contractual form, it must comply with the basic principle of an obligatio, namely an intentional personal relationship between two or more persons, in terms of which some have rights and others duties (or obligations). ${ }^{53}$ The parties to the agreement must have consensus about their intention as far as all material aspects are concerned, namely their respective duties, their intention to be bound, and their mutual consensus. ${ }^{54}$

As the concept of unconscionability is slowly but surely entrenched in contract law, the question is whether it has any applicability to trusts. Horton submits that trust law does not recognise the principle, largely because of the perception that it is unnecessary, as in many instances the founder or trustees can merely amend the trust deed. The fact is, however, that some trust clauses may substantially affect the rights of beneficiaries. He therefore submits that courts should be able to scrutinise procedurally suspicious clauses in trust deeds. ${ }^{55}$

Horton states that a founder's right to dictate how the trust assets must be used in future (even decades after his death) have the potential "to cause negative externalities". ${ }^{56} \mathrm{He}$ further submits that the unconscionability rule, with its two-pronged procedural and substantive test, is able to detect certain prejudicial clauses that are not covered effectively by other protective rules in trust law. The procedural element is ideal to identify terms that are not consonant with what an informed founder would have chosen, while the substantial aspect focuses on potentially grossly unfair effects that a clause may cause. ${ }^{57}$

It is submitted that Horton is correct in as far as he argues that many trust deeds are in the form of contracts where the contents are of little concern to the average founder. Many trust deeds in South Africa are drafted in the form of one-size-fits-all shelf documents, some of which are not even founded by the original donor himself, but are received by way of a cession. Many trust deeds are flawed ab initio as the so-called founder never had the intention to create a trust in the first place. There is still evidence in trust deeds of a period when an unfortunate practice developed among legal practitioners to make use of an independent third party (such as the attorney's personal assistant) to act as founder. The fact that the founder

52 See Peterson v Claassen 2006 (5) SA 191 (C) 196F-G; Administrators, Estate Richards v Nichol 1996 (4) SA 253 (C) 258E-G.

53 See Fouché Legal Principles of Contracts and Commercial Law (2007) 33.

54 See Van der Merwe, Van Huyssteen, Reinecke and Lubbe Kontraktereg: Algemene Beginsels (2007) 20-27.

55 Horton $2008 L R 22$

56 Horton $2008 L R 27$. He acknowledges the role of certain rules in US law to counteract these effects, like the "rule against perpetuities" and the "rules of property regimes or elective share statutes", protecting spouses from complete disinheritance. He gives a list of potentially hazardous testamentary trust stipulations.

57 Horton $2008 L R 32$ and 43. In evaluating the causes of these undesirable clauses, Horton refers to so-called "mill trusts", "self-help trusts" and the role of corporate trustees in the process of creating trust deeds that do not necessarily stipulate what the settlor had in mind. See Schmitz 2008 Alabama LR 92-94 for a critical perspective on the two-prong test. 
and trustees sign the trust deed does not necessarily prove that they have consensus regarding the contents thereof. ${ }^{58}$

Louw extends the unconscionability principle to the need for clear and simple language in documents. As a trust deed is often in the form of a contract, the parties have to be aware of all their obligations and rights in terms thereof. A substantially unconscionable agreement should be adequate ground for cancellation of the contract. Alternatively, a court may redraft contractual terms that infringe on certain consumer rights. ${ }^{59}$ The test for unconscionability has become a reality in the South African business milieu, from which trusts cannot be excluded. As trusts are often used as business vehicles and do qualify as juristic persons in terms of the Consumer Protection Act as well as the Companies Act, they should grant the same protection to affected parties as any other business form does.

Section 13 of the Trust Property Control Act allows a court to delete or vary a provision of a trust deed causing effects which, in the opinion of the court, the founder did not contemplate or foresee and which hamper the achievement of the objectives of the founder, or prejudice the interests of the beneficiaries, or are in conflict with the public interest. Thus, a two-fold requirement is set: for the section to be applicable the provision must bring about results not foreseen by the founder and it must cause at least one of three situations: (a) it must hamper the achievement of the founder's objectives; or (b) it must prejudice the interests of the beneficiaries; or (c) it must be in conflict with the public interest.

The last two requirements are of particular interest in the context of unconscionability. It is trite that a beneficiary in a discretionary trust does not have vested rights but only an expectation (spes) or contingent right. It was decided in Potgieter that once a beneficiary has received any benefits within a trust, he/she must at least be part of any change in beneficiaries of the trust. ${ }^{60}$ In terms of the privity of contract doctrine, only those who were party to a contract can be obligated by it or obtain rights in respect of it. ${ }^{61} \mathrm{As}$ a beneficiary is not a party to a trust agreement (at least not in the position of beneficiary) he/she cannot be burdened or empowered as intended by the privity doctrine. In light of the principle laid down in Potgieter, however, it seems as if the beneficiary does establish some form of "right" at acceptance of any benefit from the trust. ${ }^{62}$

The best interest of society at large is at the forefront when public policy is determined - with the latter fulfilling an important function within the

58 For an example of this type of behaviour see Potgieter $v$ Potgieter supra 637 (SCA).

59 See Louw "Simply Legal: Legal Language in South Africa" December 2011 De Rebus 22 24. Compare ss 51, 52 and 76 of the Consumer Protection Act 68 of 2008.

60 See Potgieter $v$ Potgieter supra par [18] and [29].

61 See Van Huyssteen, Van der Merwe and Maxwell Contract Law in South Africa (2010) 145147.

62 Confirmed recently in the unreported matter of Groeschke $v$ Trustee for the Time Being of the Groeschke Family Trust(NGHC) unreported case no 44105/2011 (accessed 2012-1031) par [11] 
unconscionability doctrine. ${ }^{63}$ In Everfresh it was made clear that some questions of contractual enforceability automatically raise issues of public policy. ${ }^{64}$ Although section 13 does go a long way in granting protection to beneficiaries as well as the broader public, it is limited by the requirement that the founder must not have contemplated or foreseen the particular effects of the questioned term in the contract. Where the founder has thus deliberately included the particular clause with the purpose of bringing about the dreaded consequences, the court cannot interfere - even if the provision is detrimental to a vested beneficiary or in conflict with public policy.

The intention of the legislature was therefore not to protect the beneficiaries or the interest of the public against a dubious founder, but rather to protect a negligent or ignorant founder against himself/herself. Although section 13 does not provide an encompassing protection, it is submitted that its inclusion in the Trust Property Control Act is an indication of the need to empower courts under particular circumstances to interfere with contractual trust deeds.

\section{CONCLUSION}

Smith argues convincingly that the recognition of unconscionability as a general defence may introduce a high level of uncertainty into contract law, as it may be difficult for courts to apply the procedural and substantive fairness requirements consistently. He favours the development of a numerus clausus of "situation-specific unconscionability-based rules" instead of a general defence. ${ }^{65} \mathrm{He}$ concedes, however, that, as these specific rules are better understood by way of the doctrine, they may actually influence the way courts apply the rules. ${ }^{66}$

Schmitz, on the other end of the spectrum, is not only a proponent of the need for a moralistic evaluation - instead of a purely legal view - of private contractual relationships, but even argues that the rigid, formalistic twopronged approach to unconscionability should be applied flexibly, acknowledging the safety-net aspect of the doctrine. ${ }^{67}$

Morant states that, as long as inequalities between parties to contracts are endemic, and all parties do not enter into contracts with the purpose that such contracts should be mutually fulfilling, there will be a role for a test for procedural unconscionability to play. ${ }^{68}$ It is submitted that, if procedural protection is necessary, substantive protection of the actual terms of the agreement is just another side of the same coin. While some clauses in trust

63 See Lewis 2013 THRHR 82. In Everfresh Market Virginia (Pty) Ltd v Shoprite Checkers (Pty) Ltd supra [26] Yacoob $J$ makes it clear that some questions of contractual enforceability automatically raise issues of public policy.

64 Par [26]

65 Smith Contract Theory 344.

66 Smith Contract Theory 341

67 Schmitz 2008 Alabama LR117-118.

68 Morant "The Salience of Power in the Regulation of Bargains: Procedural Unconscionability and the Importance of Context" 2006 Michigan State LR 925 959-960. 
deeds may be procedurally suspicious, others may substantially affect the rights of the beneficiaries.

The mere fact is that trust deeds may most often be amended by the founders and the trustees do not necessarily guarantee adequate protection to the individual parties and the values established by public policy. Clearly, the risk is even greater where the power of amendment rests solely upon the shoulders of the founder.

It is submitted that it will be advantageous to incorporate a principle like the unconscionability test into trust law to broaden the power of courts to interfere with the contents of both mortis causa and inter vivos trusts on procedural and substantial grounds, with a view to developing a new constitutional order that is in harmony with the spirit, purport and objects of the Constitution. ${ }^{6}$

As stated in the introduction, this article focuses on the interpretive understanding of the unconscionability doctrine in trust law - within the particular historical and descriptive reality. An interpretive process inevitably leads to a desire for efficient solutions to identified shortcomings. Prescriptive accounts should, however, not only pursue answers, but also protect constitutional integrity, legal certainty and coherent development of the law. ${ }^{70}$ It is submitted that not only has the doctrine of unconscionability become a reality in South African law of contract, but it should be embraced by trust law in establishing its future as a dynamic tool in the commercial environment.

Everfresh Market Virginia (Pty) Ltd v Shoprite Checkers (Pty) Ltd supra par [36].

70 See Smith Contract Theory 341. 